\title{
Influence of Harvest Season and Maturation of Different Sugarcane (Saccharum Spp.) Cultivars on the Chemical Composition of Alembic Brazilian Sugarcane Spirit
}

\author{
Oscar William Barbosa Fernandes ${ }^{1 *}$, Débora Faria Silva², Ananda Lima Sanson ${ }^{2}$, \\ Mauricio Xavier Coutrim², Robson José de Cássia Franco Afonso², Paulo Eichler ${ }^{3}$, \\ Fernando Santos ${ }^{4}$ \\ ${ }^{1}$ Instituto Federal do Norte Minas Gerais, Campus Salinas, Salinas, Brazil \\ ${ }^{2}$ Departament of Chemistry, Universidade Federal de Ouro Preto, Campus Morro do Cruzeiro, Ouro Preto, Brazil \\ ${ }^{3}$ Department of Chemical Engineering, Federal University of Rio Grande do Sul, Porto Alegre, Brazil \\ ${ }^{4}$ State University of Rio Grande do Sul, Porto Alegre, Brazil \\ Email: *oscarwbf@gmail.com, fernandoasantos7@gmail.com
}

How to cite this paper: Fernandes, O.W.B., Silva, D.F., Sanson, A.L., Coutrim, M.X., de Cássia Franco Afonso, R.J., Eichler, P. and Santos, F. (2017) Influence of Harvest Season and Maturation of Different Sugarcane (Saccharum Spp.) Cultivars on the Chemical Composition of Alembic Brazilian Sugarcane Spirit. Open Access Library Journal, 4: e3266. http://dx.doi.org/10.4236/oalib.1103266

Received: November 30, 2016

Accepted: January 10, 2017

Published: January 13, 2017

Copyright $\odot 2017$ by authors and Open Access Library Inc.

This work is licensed under the Creative Commons Attribution International License (CC BY 4.0).

http://creativecommons.org/licenses/by/4.0/

\begin{abstract}
Contrary to the ethanol industrial production, the quality and composition of sugar cane as raw material for the production of alembic cachaça have until now not been completely addressed. This work evaluated the influence of five different sugarcane cultivars and degree of maturation over the physicochemical composition of cachaça produced under strict controlled conditions. Three harvest seasons were used in order to obtain different stages of maturation. The sugarcane quality was assessed by the juice brix, sugarcane POL, reducing sugars, and purity. The cultivars quality did not differ within each harvest stage. However, significant quality differences were observed among sugarcane harvested in June and the other harvest months, particularly on reducing sugar content. This indicates different stages of sugarcane maturation. The 45 samples of cachaça produced from those sugarcanes were submitted to physicochemical and gas chromatography/mass spectrometry (GC/MS) qualitative analysis. The GC/MS composition pattern showed that the type of cultivar did not alter the composition of the cachaça at the same harvest stage. Otherwise, the production of acetic acid, ethyl lactate and nbutyl alcohol was higher in the first harvest (June) when compared to the others. The results from sugar cane quality and GC/MS when submitted to principal component analysis (PCA) showed consistently the separation between the groups of cachaça produced in the three seasons, indicating the influence of sugarcane ripening over the cachaça composition.
\end{abstract}




\section{Subject Areas}

Agricultural Science, Biochemistry

\section{Keywords}

Sugarcane, Cultivar, Harvest Season, Cachaça, Volatile Compounds, Gas Chromatography/Mass Spectrometry

\section{Introduction}

Cachaça (Brazilian sugarcane spirit), has been manufactured since 1536 and aside from being the most consumed distilled beverage in Brazil, it is also the third most consumed distilled beverage in the world [1]. Cachaça is produced in all regions of Brazil, thus, each brand is distinguished by its production method and the historical and cultural characteristics from each region.

Landell and Bressiani [2] studied the behavior of sugarcane quality on the basis of the harvest season in the South-Central region of Brazil. The researchers observed that in this area, sugarcane was harvested over a long period from April to November and climatic factors were responsible for a reduction in chemical and sensory quality of the cachaça. Furthermore, they found that in the period from April to June, the worst quality of cachaça was produced due to unfavorable conditions for sugarcane maturation. The reverse happens in the period from July to September and October to November: when the sugar cane quality fluctuates depending on the climatic factors.

Barbosa and Silveira [3] showed that the sugarcane plant variety is the most important aspect for the total cost of sugar and ethanol production. It is the foundation that underpins all other sugarcane based production technologies. Through several breeding programs, Brazil has become an international leader in the area with regard to obtaining improved varieties to meet high yield on sugar and ethanol production. High yield plant varieties, best suited to the production of sugar and alcohol, have also gained importance for meeting the production of high quality cachaças [4].

According to Coleti and Stupielo [5], the use of supplemental irrigation has recently been introduced to enable a new type of sugarcane cultivation that shortens the crop cycle. The plantation starts in the southern hemisphere in the semi-tropical winter, dry season, covering the months of June, July, August and the first half of September. Through controlled irrigation, the crop develops well and can be harvested at the same period in the following year, achieving ideal maturation conditions, which will result in better sugarcane quality.

Cachaça's secondary compounds or congeners are substances formed during the alcoholic fermentation alongside ethyl alcohol and carbon dioxide [6]. The origin and quantity of these compounds on distilled beverages are determined, at different levels, by the characteristics of the raw material, fermentation, distillation and aging. The main classes of congeners formed during the fermentation 
belong to functional groups of acids, esters, aldehydes, alcohols. There are also smaller proportions of ketones, phenolics, amines and mercaptan [7].

According to Leaute [8], at the distillation process of cachaça the volatile compounds can be classified by their boiling point and miscibility in alcohol and water. Compounds such as acetaldehyde (bp $21^{\circ} \mathrm{C}$ ) and ethyl acetate (bp $77^{\circ} \mathrm{C}$ ) are soluble in ethanol and partially in water. Higher alcohols such as isoamyl alcohol $\left(131^{\circ} \mathrm{C}\right)$ are miscible in ethanol and partially soluble in water. Fat acids and their esters have higher bp than water and are miscible in ethanol and partially soluble in water. Other compounds such as acetic acid (bp $\left.110^{\circ} \mathrm{C}\right)$, ethyl lactate (bp $151^{\circ} \mathrm{C}-155^{\circ} \mathrm{C}$ ) and 2-methyl-1-butanol (bp $127.5^{\circ} \mathrm{C}$ ) and furfural (bp $162^{\circ} \mathrm{C}$ ) are very soluble in water. Therefore, the distribution of congeners during distillation is determined by their volatilities and solubilities.

Some chemical constituents present in cachaça are considered to be of significant importance. The Brazilian legislation [9] endorsed a technical regulation for setting quality standards for cachaça. Currently, the cachaça must meet with maximum and minimum limits of inorganics and organic volatile congeners and contaminants in its composition. Restrictions are enforced to moderate the influence of some components to the public health and therefore all cachaça produced in Brazil must meet international standards.

Some extensive work has been carried out to evaluate the chemical composition of volatile compounds in cachaça samples by chromatography. Nascimento et al. [10] described a qualitative and quantitative high-performance liquid chromatographic analysis of aldehydes in cachaça and in other distilled alcoholic beverages. Nascimento et al. [11] determined esters in cachaça and other distilled spirits by gas chromatography-mass spectrometry (GC-MS). More recently, Souza et al. [12] applied a comprehensive two-dimensional gas chromatography for the determination of volatile compounds in cachaça. The effects of bidistillation, and the use of charcoal filtration in the production of artisan cachaça, as well as the effects of multi-distillation on volatile products in commercial cachaça were investigated. More than 100 compounds, comprising various homologous series were tentatively identified using MS library matching and comparison with retention indices.

The composition of fermented and distilled beverages is dependent on the quality of its raw material. For example, wine chemical composition, sensorial characteristics and quality are related to the grape varietal, sugar content and also grape maturity. Kontoudakis et al. [13] presented the influence of the heterogeneity of grape phenolic maturity on wine composition and quality. Bindon et al. [14] demonstrated the relationships between harvest time and wine composition, where the volatiles were significantly influenced by harvest date where isobutyl methoxypyrazine, C6 alcohols and hexyl acetate, all of which decreased as ripening progressed.

The quality of sugar cane as raw material for obtaining high quality alembic cachaça has to the best of our knowledge not been studied. The chemical composition of the sugarcane is directly related to the time of ripening, which is ex- 
pected to have influence in the physical-chemical and microbiological characteristics of the crop. Since cachaça production does not involve sterilization of the sugarcane juice, it is expected that this characteristics will later bring changes at the fermentation process and the distillated composition.

The current study provides a general overview of how the cachaça volatile composition can be influenced by the temporal changes in sugarcane chemical and microbiological composition during ripening. The experiments in this study have been sought to incorporate the influence of five sugarcane cultivars composition at three different harvest times in order to account for differences in chemical composition of distilled sugarcane spirit.

\section{Materials and Methods}

Experimental design

A full factorial experimental design with 2 variables, cultivar with 5 levels and ripening season with 3 levels, with 3 replicates was set to evaluate the influence of the sugarcane quality on variations in the cachaça composition, produced under the same fermentation and distillation conditions. The detailed experiments are described below.

Cultivars of sugar cane used

The planting of sugarcane cultivars, that provided the raw material for the manufacture of cachaça samples, was held in the month of July 2009, in Salinas-Minas Gerais State, Brazil ( $16^{\circ} 18^{\prime} 01.2^{\prime \prime}$ and $15^{\circ} 50^{\prime} 59.4^{\prime \prime}$ south $42^{\circ} 37^{\prime} 00.2^{\prime \prime}$ and $41^{\circ} 45^{\prime} 13.6^{\prime \prime}$ west). The cultivars planted were the SP79-1011, Root, SP80-1842 and RB765418, obtained through the Federal University of Viçosa (UFV), which are among those currently recommended to produce sugar and alcohol [15]. In addition to these, it was also used the cultivar Java, which was already planted in Salinas Campus, the most traditional in the region.

Plantation and harvest season of sugarcane cultivars

Five sites of $600 \mathrm{~m}^{2}$ were planted, one for each plant, equipped with sprinkler irrigation system. The cultural practices carried out were the same for all cultivars. The soil in which they were installed, was characterized as dark red eutrophic latosoil with strong corrugated relief. The fertilization was done according to soil analysis and requirements for the culture [16]. Irrigation was performed weekly, with blade of water determined by the potential evapotranspiration obtained by Thorntwaite method [17]. Water collectors were installed at various points of the crop in order to quantify the water slide that was effectively applied. Irrigation was suspended from May 2010.

There were three crops of sugarcane cultivars, in three distinct seasons, so to check the interference of the harvest season in the parameters of quality of the raw and distillated material. The three seasons were: 1st season-the second half of June 2010; 2nd season—the second half of August 2010 and 3rd season—first fortnight of October 2010.

Sugar cane quality control

The juice brix, juice pol, sugarcane pol, apparent purity, juice reducing sugars, 
sugarcane reducing sugars, total reducing sugars, and total recoverable sugar analysis were performed at Jatiboca distillery laboratory, located in UrucâniaMG, according to CONSECANA [18] methods.

Pilot-scale fermentation

Fermentation assays were performed on a pilot scale during each harvest season, using $50 \mathrm{~L}$ stainless steel vats containing sugarcane juice. Previously, sugarcane was washed and the broth extraction done in an appropriated milling, just after harvest, and filtered in a stainless steel sieve to remove wastes (bits of bagasse). Finally, sugarcane juice was diluted in deionized water to $15^{\circ} \mathrm{Brix}$.

Each fermentative cycle took approximately 24 hours and it was initiated when the vat containing the remaining culture (termed foot vat) is filled with 30 $\mathrm{L}$ fresh sugarcane juice diluted to $15^{\circ}$ Brix. A fermentative cycle was considered finalized when sugar consumption reaches $3^{\circ}$ Brix [6].

The strain used in this work was isolated from cachaça distilleries placed in Salinas, Minas Gerais, Brazil. Saccharomyces cerevisiae strain LBCM 678 was isolated from fifteen different distilleries and selected according to methodology previously described [19]. Yeast cells propagation was made into 20 L plastic buckets, previously cleaned with $70 \%$ ethanol. The vat containing sugarcane juice was supplemented with $1 \%$ yeast extract and incubated at $30^{\circ} \mathrm{C}$ under constant aeration using air compressor with pumping capacity of $4.5 \mathrm{~L}$ of air $\min ^{-1.6}$. This last procedure was repeated until the volume of sediment cells $(2.0 \mathrm{~L}$ per vat) was achieved at cell concentration of approximately $10^{9} \mathrm{CFU} \mathrm{mL} \mathrm{m}^{-1}$.

Three bath feeding fermentations for each cultivar of sugarcane were conducted in three different seasons, making a total of forty-five fermentations and distillations.

Distillation

After the fermentation process the wine was immediately distilled in copper alembic (Image 1), with capacity for $40 \mathrm{~L}$ of useful volume of fermented mash. The alembic was directed heated by the use of liquefied petroleum gas fire. The total distillate was split during distillation in three fractions called head, heart and tail, collected in the respective proportions of $5 \%, 80 \%$ and $15 \%$ of the distilled volume. The heart fractions (cachaça) were bottled in glass and used for the composition studies.

Analysis of volatile compounds by GC-MS

The volatile compounds from cachaça samples were extracted by liquid/liquid extraction using $2.0 \mathrm{~mL}$ of dichloromethane (HPLC grade, J. T. Baker) and $0.5 \mathrm{~g}$ of $\mathrm{NaCl}$ (Synth-A.C.S.) and $8.0 \mathrm{~mL}$ of each cachaça sample in stoppered flasks of $40 \mathrm{~mL}$. The agitation of the samples was made using a vortex type agitator (Velp Scientifica, $2000 \mathrm{RPM}$ ) for $5 \mathrm{~min}$. After phase separation, the dicloromethane fraction was collected by $1.0 \mathrm{~mL}$ micropipette and transferred to a $2.0 \mathrm{~mL}$ sealed vial. To the original samples were added $50 \mu \mathrm{L}$ of $10 \mu \mathrm{g} \cdot \mathrm{L}^{-1}$ of labeled $\mathrm{D}_{10}$ Anthracene (Sigma Aldrich) as surrogate.

The chromatographic analysis of volatile substances were performed by a GC-MS system QP2010 Plus (Shimadzu, Kyoto, Japan), equipped with electron 


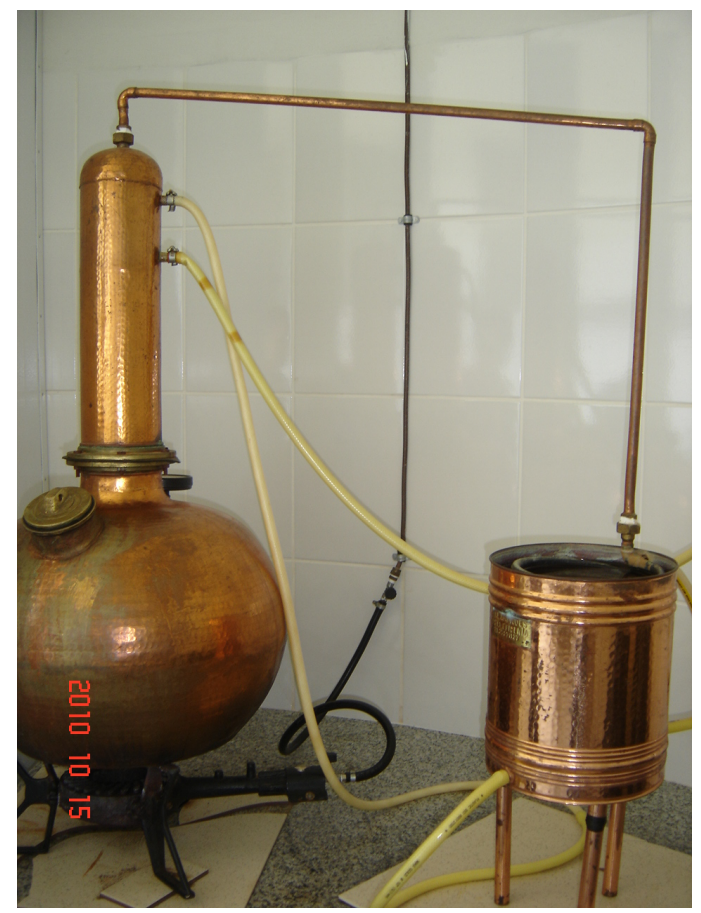

Image 1. Cachaça distillation plant.

ionization source $(70 \mathrm{eV})$ and quadrupole mass analyzer. A column Elite- polyethylene glycol Wax, $30 \mathrm{~m} \times 0.25 \mathrm{~mm} \times 0.25 \mu \mathrm{m}$ (PerkinElmer, Shelton, E.U.A.) was employed.

The chromatographic analyses were carried out under the following conditions, column oven temperature $35^{\circ} \mathrm{C}$ to $220^{\circ} \mathrm{C}$ at $5^{\circ} \mathrm{C} \cdot \mathrm{min}^{-1}, 220^{\circ} \mathrm{C}$ for $10 \mathrm{~min}$; the injected volume was $2.0 \mu \mathrm{L}, 0.5$ min splitless mode; split ratio $1 / 15$, septum purge $15 \mathrm{ml} \cdot \mathrm{min}^{-1}$. The helium carrier gas flow was $1.24 \mathrm{~mL} / \mathrm{min}$; linear velocity adjusted to $45 \mathrm{~m} \cdot \mathrm{min}^{-1}$. The injector temperature was $240^{\circ} \mathrm{C}$, the GC/MS transfer line was $240^{\circ} \mathrm{C}$ and ion source was $200^{\circ} \mathrm{C}$. The mass spectrometer operated in fullscan mode (scan), acquiring from 40 to $400 \mathrm{~m} / \mathrm{z}$. and at SIM mode 188, 94 and $80 \mathrm{~m} / \mathrm{z}$ for the surrogate.

The software GC-MS-solution v. 2.50 SU3 (Shimadzu Corp., Kyoto, Japan) was used for the acquisition of mass spectra and chromatograms. To compare the relative intensities, the analyte peak areas were normalized to the peak area of $\mathrm{m} / z 188$ from the surrogate, labeled $\mathrm{D}_{10}$ Anthracene.

Statistical analysis

For a better exploratory interpretation of the results obtained for the various compounds found in cachaça samples, principal components analysis (PCA) of correlation matrixes were done using MINITAB ${ }^{\circledR}$ statistical software, version 14 for Windows (Minitab Inc: State College, Pennsylvania).

The analyses of variance were conducted using the statistical software GraphPad Prism ${ }^{\circledR}$, version 5.0 for Windows (San Diego, California-USA). The normality of the data was checked using the Kolmogorov Smirnov. The parametric data were evaluated using the table test ANOVA followed by Tukey post-test. The nonparametric data were earned by Friedman's test with post-test Duns. The 
statistical significance was $95 \%(\mathrm{P}<0.05)$.

The original data set consisted of 29 analytes (variables) and forty-five samples (three replicates of three seasons of harvest of five sugarcane cultivars distillations), generating an data array of $[X=(29,45)]$ where each row represents a sample and each column, a measured chromatographic area of variables.

\section{Results and Discussion}

The results obtained from the composition of five cultivars of sugarcane in three seasons of harvest (available as supporting information) were evaluated using multivariate analysis through principal component analysis (PCA). It was observed that the samples obtained from the first harvest season (June) had its own characteristics in relation to other harvest times, thus forming a distinct group (Figure 1).

The sugarcane maturation stage can be assigned by the reducing sugar and \% Pol. According to Vasconcelos 2010 [20] and Fernandes 2011, [21] reducing sugar content above $0.5 \%$ and $\%$ Pol below $16 \%$ is characteristic of immature sugarcane. Despite the possible analytical error, sugarcane over maturation can be assigned when \% Pol is above $18 \%$. As a result of the natural process of maturation, there was a significant raise in the quality of the raw material at the second and third harvest, as showed in Table 1 through an increase on the percentage of brix of the juice, sugarcane pol, apparent purity, and a decrease in reducing sugar levels. The same behavior was observed in all cultivars (Table 1).

According to Coleti and Stupielo [5], when the use of supplemental irrigation was employed in June, July, August and the first half of September, cultivars expressed differences in behavior, with regard to the degree of ripeness, within

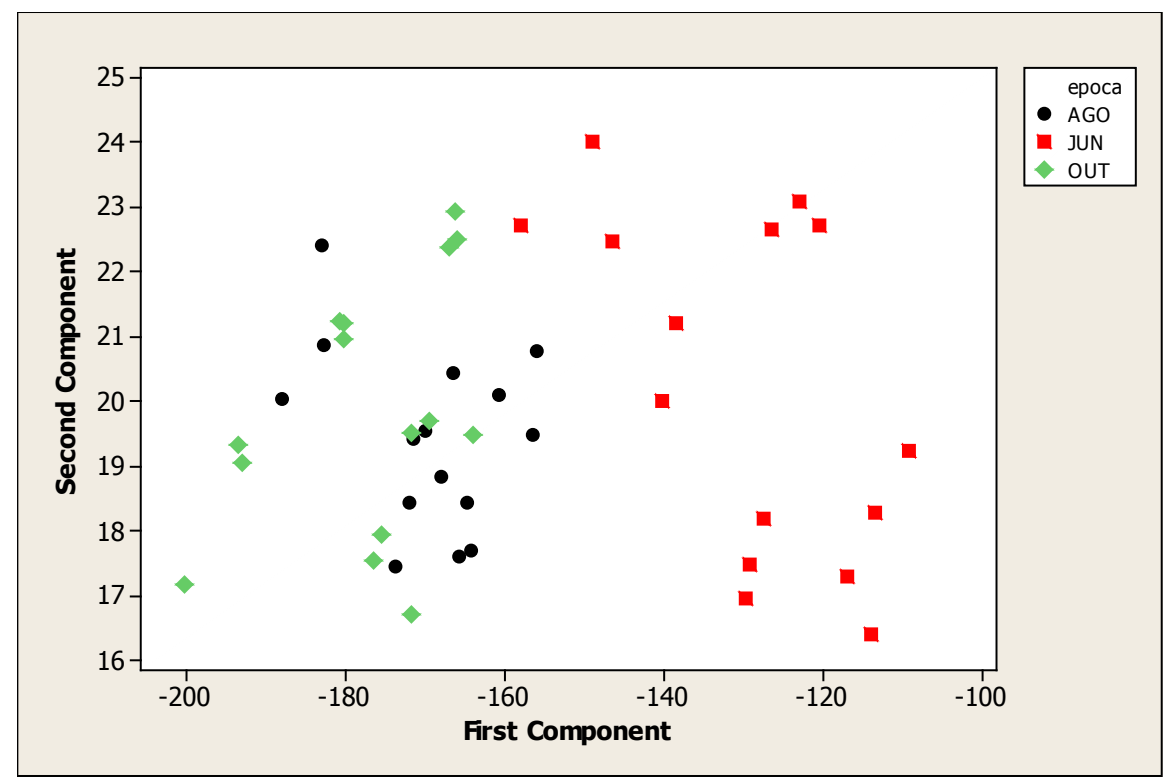

Figure 1. PCA score plot from sugarcane quality analysis of raw materials of five different cultivars harvested in three seasons (June, August, and October). The variables used were juice brix, apparent purity, fiber, sugarcane pol, sugarcane reducing sugars, total sucargane reducing sugars, total recoverable sugars and humidity. 
Table 1. Mean values for sugarcane quality parameters in five cultivars harvested at June, August and October.

\begin{tabular}{ccccccc}
\hline \multirow{2}{*}{$\begin{array}{c}\text { TECHNOLOGICAL } \\
\text { PARAMETERS }\end{array}$} & \multicolumn{5}{c}{ CULTIVARS } & MEAN \\
\cline { 2 - 6 } & RB72454 & SP79-1011 & SP80-1842 & JAVA & RB765418 & VALUES \\
\hline Juice brix \%* & $17.66 \mathrm{a}$ & $16.93 \mathrm{a}$ & $20.8 \mathrm{a}$ & $18.13 \mathrm{a}$ & $17.5 \mathrm{a}$ & $18.20 \mathrm{~A}$ \\
Sugarcane Pol \%* & $12.29 \mathrm{a}$ & $11.85 \mathrm{a}$ & $15.18 \mathrm{a}$ & $12.61 \mathrm{a}$ & $12.18 \mathrm{a}$ & $12.82 \mathrm{~A}$ \\
Apparent purity \%* & $79.30 \mathrm{a}$ & $80.56 \mathrm{a}$ & $87.12 \mathrm{a}$ & $79.79 \mathrm{a}$ & $82.98 \mathrm{a}$ & $81.95 \mathrm{~A}$ \\
Reducing sugars \%* & $0.80 \mathrm{a}$ & $0.76 \mathrm{a}$ & $0.54 \mathrm{a}$ & $0.78 \mathrm{a}$ & $0.66 \mathrm{a}$ & $0.70 \mathrm{AB}$ \\
& & & AUGUST & & \\
Juice brix \%* & $22.33 \mathrm{a}$ & $22.5 \mathrm{a}$ & $24.73 \mathrm{ab}$ & $23.26 \mathrm{a}$ & $21.66 \mathrm{ac}$ & $22.89 \mathrm{~B}$ \\
Sugarcane Pol \%* & $16.64 \mathrm{a}$ & $17.14 \mathrm{a}$ & $18.78 \mathrm{ac}$ & $17.31 \mathrm{a}$ & $15.87 \mathrm{ac}$ & $17.14 \mathrm{~B}$ \\
Apparent purity \%* & $85.35 \mathrm{a}$ & $87.96 \mathrm{a}$ & $89.97 \mathrm{a}$ & $85.99 \mathrm{a}$ & $85.65 \mathrm{a}$ & $86.98 \mathrm{~B}$ \\
Reducing sugars \%* & $0.62 \mathrm{a}$ & $0.54 \mathrm{a}$ & $0.47 \mathrm{a}$ & $0.59 \mathrm{a}$ & $0.60 \mathrm{a}$ & $0.56 \mathrm{~A}$ \\
& & & OCTOBER & & & \\
Juice brix \%* & $23.3 \mathrm{a}$ & $22.66 \mathrm{a}$ & $23.8 \mathrm{a}$ & $25.66 \mathrm{ab}$ & $22.33 \mathrm{ac}$ & $23.55 \mathrm{~B}$ \\
Sugarcane Pol \%* & $17.68 \mathrm{a}$ & $17.03 \mathrm{a}$ & $18.35 \mathrm{a}$ & $19.95 \mathrm{ab}$ & $16.84 \mathrm{ac}$ & $17.97 \mathrm{~B}$ \\
Apparent purity \%* & $86.46 \mathrm{a}$ & $87.15 \mathrm{a}$ & $90.313 \mathrm{a}$ & $89.94 \mathrm{a}$ & $89.34 \mathrm{a}$ & $88.64 \mathrm{~B}$ \\
Reducing sugars \%* & $0.59 \mathrm{a}$ & $0.56 \mathrm{a}$ & $0.46 \mathrm{a}$ & $0.48 \mathrm{a}$ & $0.48 \mathrm{a}$ & $0.51 \mathrm{AC}$ \\
\hline
\end{tabular}

${ }^{*} \mathrm{~N}=3-$ Mean values followed by the same small letter do not differ on the line and in the capital, within a single parameter, the $5 \%$ level by the Friedman test followed by post-test Dunns.

Table 2. Monthly average of rainfall (R), sugarcane evapotranspiration (SE), irrigation (Ir), monthly sunlight hours (MS) and relative humidity (RH) from July of 2009 to July 2010 .

\begin{tabular}{cccccc}
\hline Month/year & $\mathrm{R}(\mathrm{mm})$ & $\mathrm{SE}(\mathrm{mm})$ & $\mathrm{Ir}(\mathrm{mm})$ & $\mathrm{MS}(\mathrm{h})$ & $\mathrm{RH}(\%)$ \\
\hline $07 / 2009$ & 0 & 32.96 & 32.96 & 212 & 69.82 \\
$08 / 2009$ & 6.5 & 39.55 & 33.05 & 184.2 & 62.48 \\
$09 / 2009$ & 2.6 & 91.36 & 88.76 & 219 & 54.76 \\
$10 / 2009$ & 186.5 & 120.72 & 0 & 171.9 & 68.54 \\
$11 / 2009$ & 56.9 & 144.82 & 87.92 & 223.1 & 72.47 \\
$12 / 2009$ & 79.5 & 169.98 & 90.48 & 177.1 & 74.99 \\
$01 / 2010$ & 28.3 & 183.19 & 154.89 & 260.8 & 64.07 \\
$02 / 2010$ & 88.8 & 159.48 & 70.68 & 227 & 64.65 \\
$03 / 2010$ & 247.7 & 159.54 & 0.00 & 198.1 & 81.34 \\
$04 / 2010$ & 75 & 102.80 & 27.80 & 189.5 & 80.63 \\
$05 / 2010$ & 16.6 & 61.32 & 44.72 & 178.5 & 80.24 \\
$06 / 2010$ & 0.7 & 31.15 & 0 & 191.9 & 72.15 \\
$07 / 2010$ & 6 & 32.59 & 0 & 182.5 & 65.24 \\
\hline
\end{tabular}

each harvest season and all showed significantly higher maturity level in the second and third harvest time. However, significant differences were detected in the juice brix\% and sugarcane Pol \% between cultivars SP80-1842 and RB765418, both of early maturation, and between RB765418 and Java cultivars, in analyses carried out in August and October respectively (Table 1). Table 2 shows the monthly average of rainfall, sugarcane evapotranspiration, irrigation, monthly sunlight hours and relative humidity from July of 2009 to July 2010. Data of 
monthly sunlight hours and relative humidity was obtained from the National Institute of Meteorology (INMET) website. Figure 2(a) and Figure 2(b) show

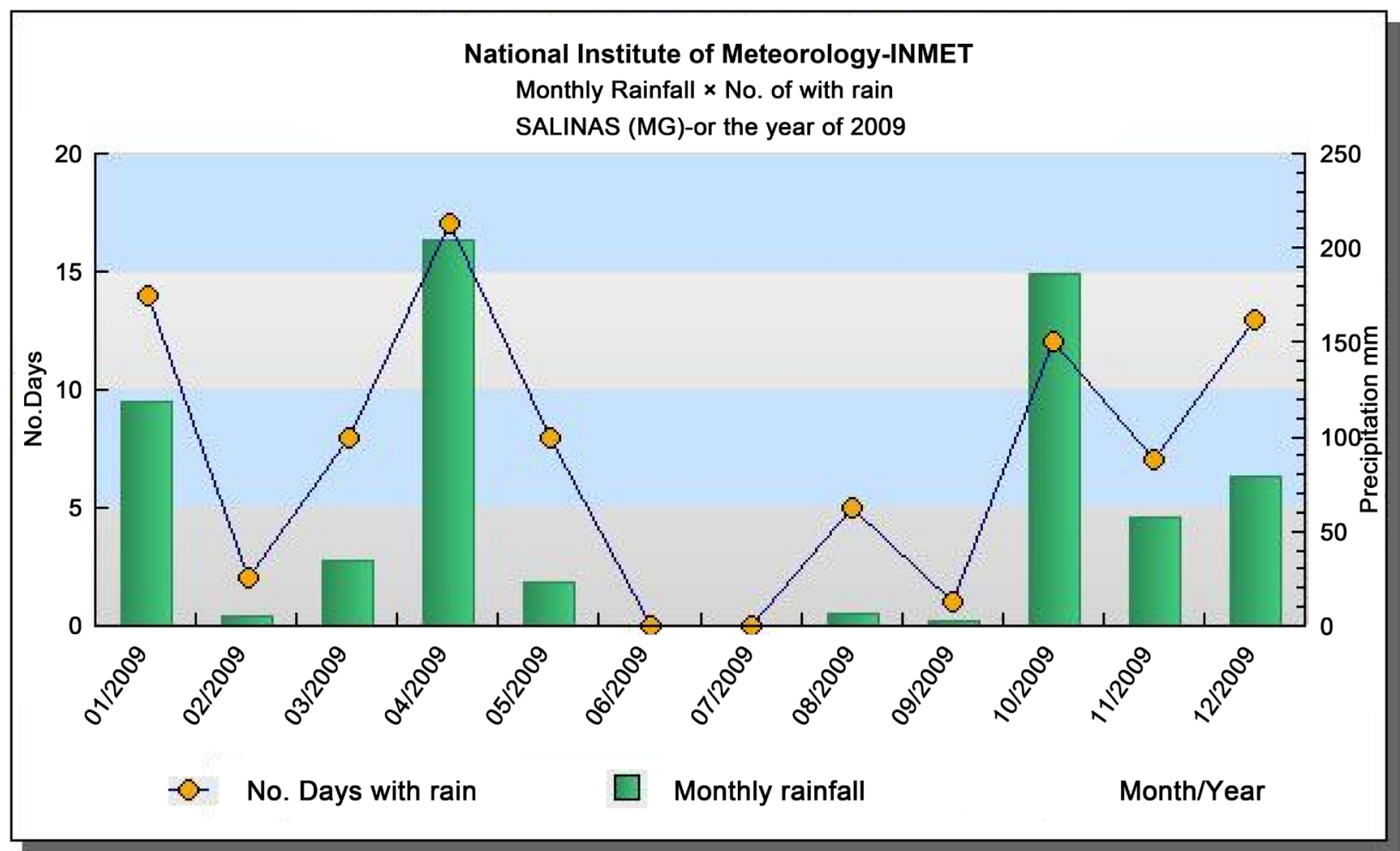

(a)

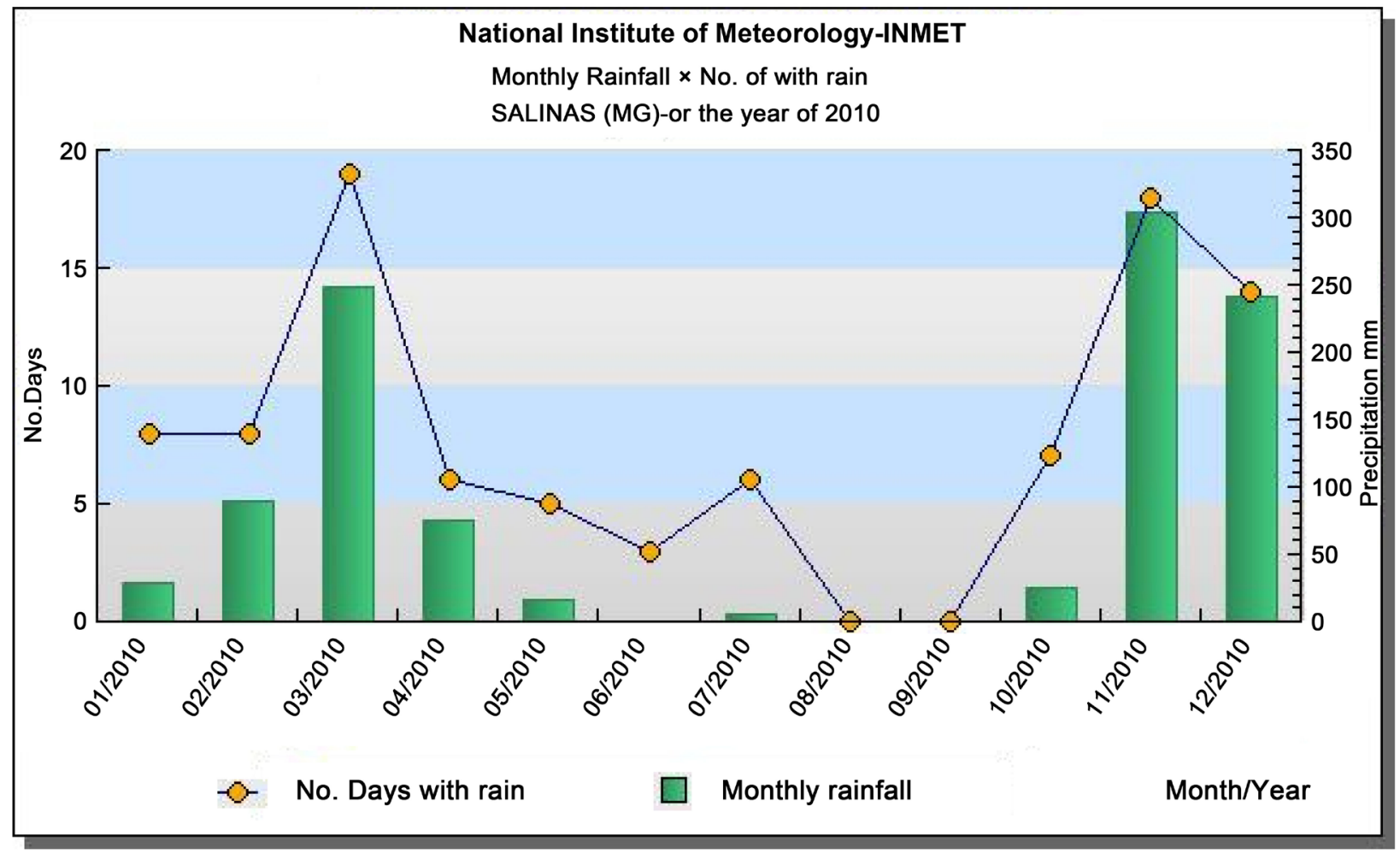

(b)

Figure 2. (a) Number of days with rain and monthly rainfall for 2009; (b) Number of days with rain and monthly rainfall for 2010. 
data for number of days with rain and monthly rainfall for the years of 2009 and 2010, respectively, and Figure 3(a) and Figure 3(b) show the monthly average temperature for the years of 2009 and 2010, respectively, all data obtained from INMET [22].

Figure 4 shows a typical chromatogram of cachaça samples run for $45 \mathrm{mi}-$

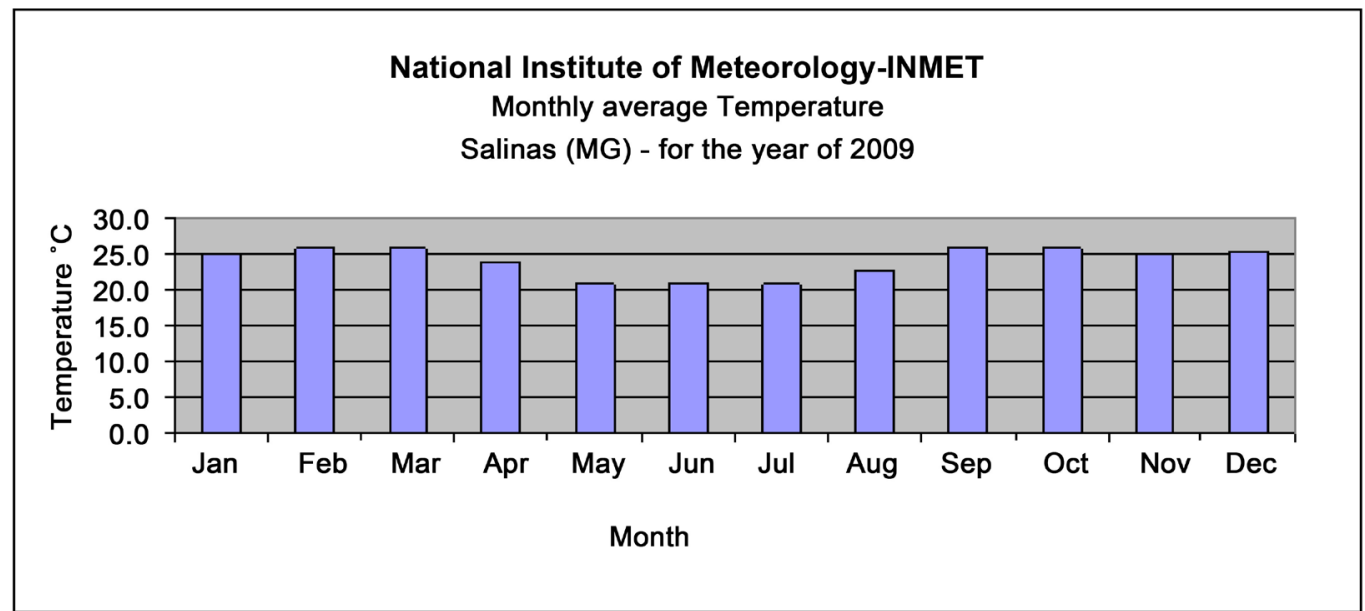

(a)

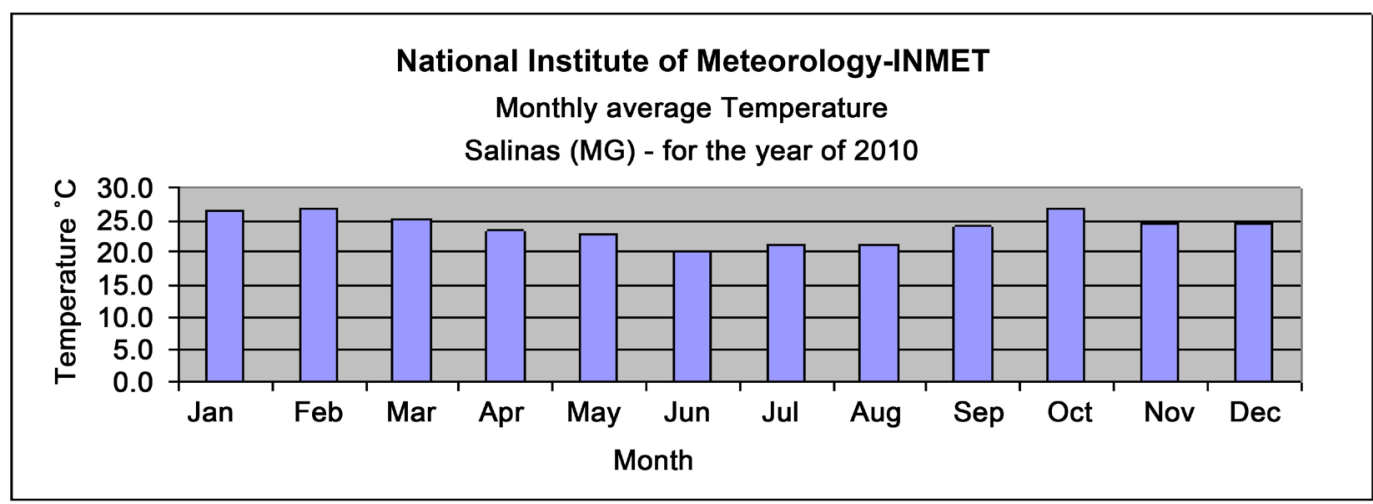

(b)

Figure 3. (a) Monthly average temperature for 2009; (b) Monthly average temperature for 2010.

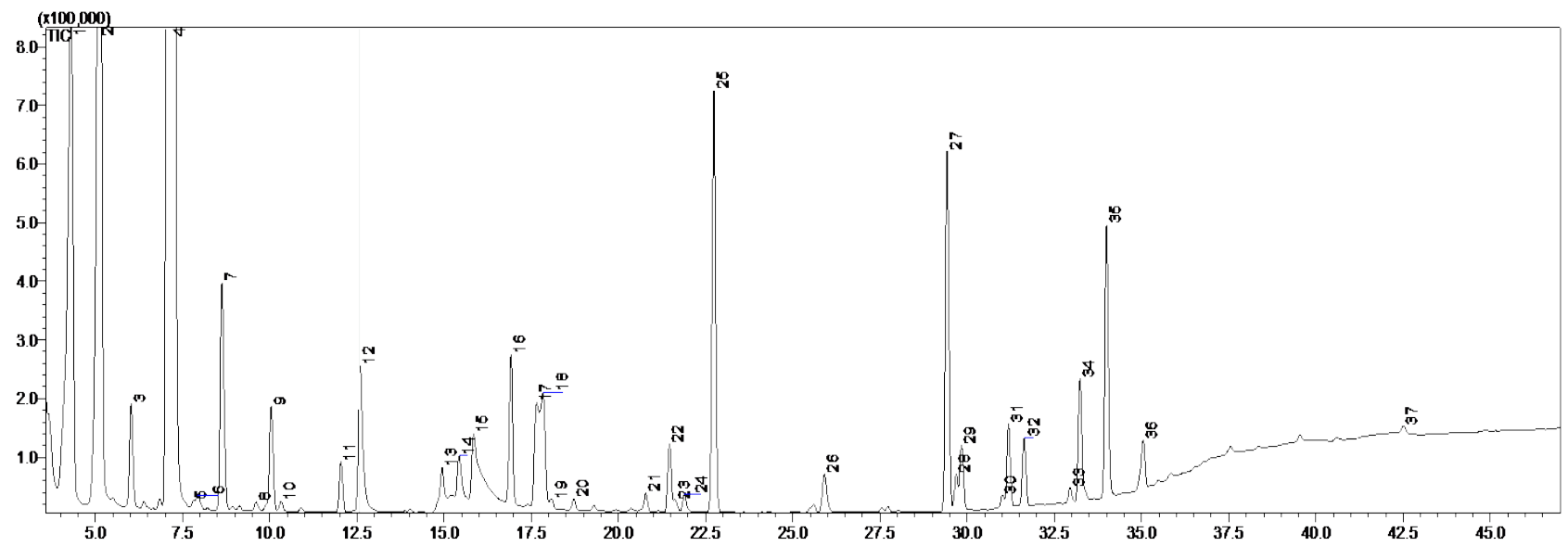

Figure 4. Total ion current chromatogram obtained by GC-MS corresponding to the sample of cachaça. Among the volatiles identified in 37 related chromatogram, peak: (2) isobutyl alcohol, (3) butyl alcohol, (4) isoamyl alcohol, (6) ethyl lactate (8) acetic acid. 
nutes, demonstrating the presence of alcohols, esters, carboxylic acids.

The principal component analysis (PCA) two dimensional score plot (Figure 5 ) indicates that the volatiles compositions of cachaças are distinctly grouped according to the three sugarcane seasons of ripening. There is no evident distinction among the congener compositions of the five different sugarcane cultivars.

The GC/MS results showed differences in the concentrations of volatile compounds in the 45 produced cachaça samples from the 5 different cultivars of sugarcane, harvested in three seasons. Greater variations were observed on contents of acetic acid, ethyl acetate and ethyl lactate among the three ripening seasons.

It can be observed in Figure 6, that the median values of the relative TIC chromatographic peak area for acetic acid in cachaça produced in the first seasons, harvested in June, were significantly higher when compared to August and October. It was also identified, on sugarcane quality tests that high reducing sugar content of raw material occurred in the same harvest time.

Figure 7 shows the relative TIC chromatogram peak areas for acetic acid produced by each sugarcane cultivar at three harvest times. It can be observed that acetic acid response was higher for all cultivars at the first harvest season (June). The ANOVA test also confirms that. The cachaça produced from the cultivar SP79-1011, considered of average maturity, showed the highest median value for acetic acid in the first season when compared to the other cultivars. These values can be correlated to the results of sugarcane raw material quality (Brix, apparent Purity \% sugarcane Pol \% and reducing sugars \%) that presented the lowest Brix and the highest reducing sugar contents, characteristic of lower maturity and worst raw material quality.

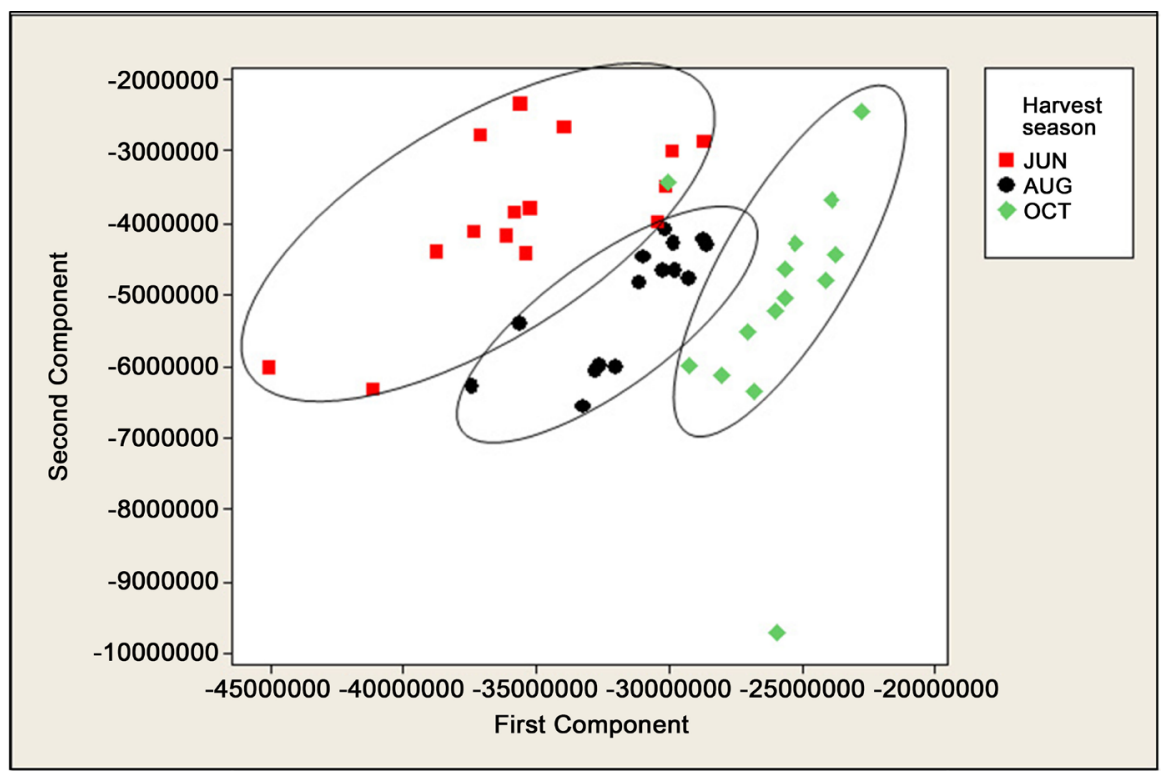

Figure 5. PCA scores plot for GC/MS analysis of volatile compounds in 45 cachaça samples produced with different sugarcane cultivars harvested in three seasons. A total of 29 variables were used, among alcohols, esters, and carboxylic acids. 


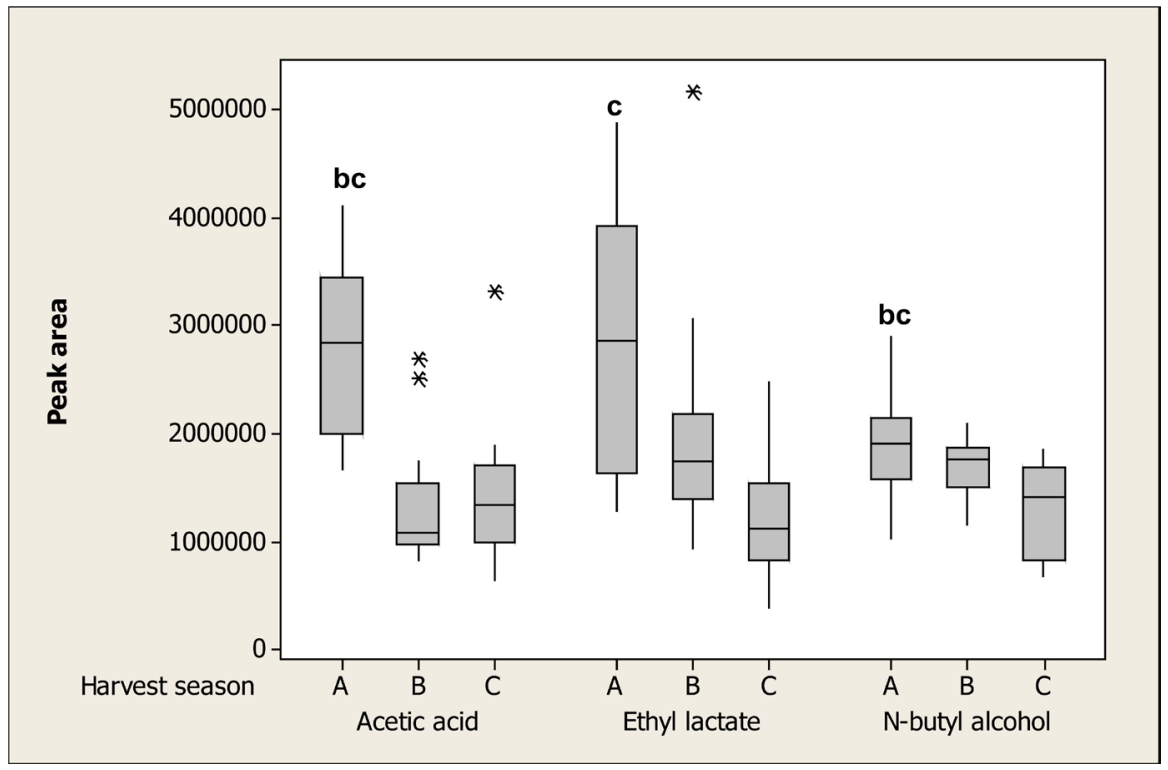

Figure 6. Median value and percentiles $25 \%$ and $75 \%$ of chromatographic peak areas referring to acetic acid (peak area values multiplied by four), ethyl lactate, and n-butyl alcohol (peak area values multiplied by four) present in cachaça samples produced from different sugarcane cultivars harvested in three maturation seasons (A, B, C). The letters $b, c$ represent statistical difference between June and the other seasons, the letter $c$ represent statistical difference between June and October, and the letter $c^{\star}$ represent statistical difference between August and October $(p<0.0001)$. Friedman followed by Dunns post-test.

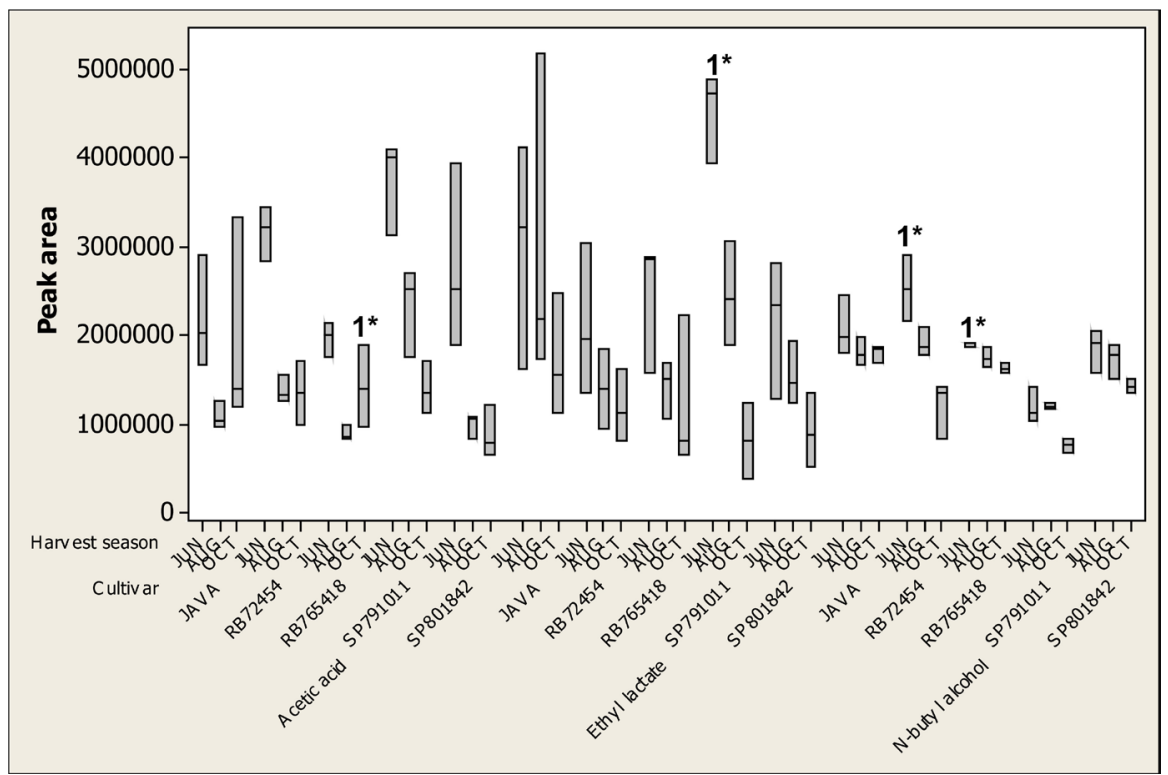

Figure 7. Median value and percentiles $25 \%$ and $75 \%$ of chromatographic peak areas referring to acetic acid (peak area values multiplied by four), ethyl lactate, and n-butyl alcohol (peak area values multiplied by four) present in cachaça samples of each sugarcane cultivars harvested in different maturation seasons. $1^{\star}$ represent statistical difference between June and October $(\mathrm{p}<0.0001)$. Friedman followed by Dunns post-test.

According to Ripoli and Ripoli,22 the increase on reducing sugars contents in sugarcane has been correlated with bacterial contamination at the beginning of 
the harvest, when the sugar cane has not reached the ideal point of ripeness. According to Stupielo [23], the bacterial activities are important for the processing of sugarcane, and they are responsible for the presence of metabolic byproducts such as acetic and lactic acids.

The relative high concentrations of reducing sugars and low sucrose and purity content are attributed to low quality of sugarcane. The sugarcane maturation indexes are factors that influence on bacterial contamination. The distillated acidity can be attributed to the contamination of the cane or the mash fermentation by acetic, lactic and other bacteria. Those microorganisms can cause the acetic fermentation of the substrate, increasing the acidity and reducing the efficiency of ethanol production [24].

The volatile acidity, expressed as acetic acid is quantitatively predominant and its concentration varies from $60 \%$ to $95 \%$ of the total acidity. The excess acidity promotes unwanted taste and slightly "aggressive" in sugarcane spirit, depreciating the quality of the drink [25] [26]. In a published work on sensory quality of cachaça, Odello et al. [27] indicated that the acidity as being one of the main factors for the definition of qualitative profile to be evaluated on sensorial analysis of cachaça, decreasing the score and preference for the drink.

Ethyl acetate is the most abundant ester in distilled beverages, followed by ethyl lactate. Nascimento [28] assessed the concentration of esters in 136 samples of spirits. It was noted that the ethyl acetate represented $59.3 \%$ of the total concentration of esters and ethyl lactate $36.2 \%$, being the second most abundant ester.

The presences of these esters are related to contamination of mash by bacteria, Lactobacillus spp. which are responsible for lactic fermentation [28]. In this work, in all analyzed cachaça samples were detected the presence of ethyl ester and ethyl lactate. Figure 6 shows that the values of the medians for TIC chromatogram peaks of ethyl lactate were higher in the first season and that this differed statistically from the third season.

It was also verified that the ethyl lactate presented greater values of the chromatographic peak area medians in cachaça samples produced by each cultivar of sugar cane in the month of June (Figure 7).

$\mathrm{N}$-butyl alcohol (1-butanol) is generated by bacteria that may compromise the quality of cachaça [29]. The literature has shown that high concentrations of reducing sugars in immature sugarcane or "green" are precursors of bacterial contamination in the fermentation of the must. In this study, it was found the same correlation between higher reducing sugars content and higher chromatographic peak area of n-butyl alcohol. This is evident in samples of cachaça produced in June. They were statistically higher in relation to other harvest times (Figure 6).

The results of analysis of variance followed by post-tests for cachaça samples produced by each sugarcane cultivar in the months of June, August and October are showed in Figure 7. The medium values of the chromatographic peak area for n-butyl alcohol in each harvest time showed similar behavior to that of acetic acid and esters. It was observed that the cachaça samples from the cultivars root 
and RB765418 showed values of the medians of 1-butanol significantly higher in the first harvest season.

\section{Conclusions}

The 5 sugarcane cultivars (Root, SP79-1011, SP80-1842, Java and RB765418) did not express any statistically significant differences on chemical composition when compared at each harvest season (June, August, and October). However, all cultivars showed significant higher quality level (Brix of sugarcane juice, POL, apparent purity and cane sugars) in the second and third harvest season. The principal component analysis (PCA) of the values related to the sugarcane quality parameters for the five cultivars indicated that samples of reeds harvested in June had distinct characteristics in relation to other harvest times, thus forming a discriminated sample group.

As for the sugarcane quality parameters, the comparative results of gas chromatography analysis of volatiles congeners of cachaça samples showed that the type of cultivar did not interfere in the formation of compounds present at each harvest season. When assessing the congener volatile compositions on each harvest season, it was observed statistically significant differences among the three harvest seasons, mainly as regards the production of acetic acid, ethyl lactate and n-butyl alcohol. Such substances showed a significantly higher qualitative profile in the first harvest season (June) in relation to other times. These results submitted to PCA produced 3 distinct groups, consistent to the separation of cachaça samples produced in each season, and characteristic of different stages of sugarcane ripening.

Through this study, it was observed that the harvest season, the sugarcane cultivars, the reducing sugar and sucrose content should be considered as reference for the alembic cachaça production. The quality of the raw materials harvested should be considered as indicators for the production of cachaça with better chemical and sensory characteristics. Although it can be seen that harvest season and maturation are important factors for chemical composition of cachaça, since the study of these influences is still in the early phases, more studies are needed to reveal the explanations for this interaction.

\section{Acknowledgements}

The authors would like to thank Dr. Jason Guy Taylor (UFOP) for insightful discussion and for reviewing the manuscript for its English usage. We also acknowledge the financial support from UFOP, CAPES (DINTER), FINEP, FAPEMIG, and CNPq.

\section{References}

[1] Masson, J. (2009) Determinação dos teores de carbamato de etila e acroleína em aguardentes de cana produzidas em Minas Gerais. $\mathrm{PhD}$ Thesis, Universidade Federal de Lavras, Brazil.

[2] Landell, M.G.A. and Bressiani, J.A. (2008) Melhoramento genético, caracterização e 
manejo varietal. In: Miranda, L.L.D., Vasconcelos, A.C.M. and Landell, M.G.A., Eds., Cana-de-açúcar, Instituto Agronômico, Campinas, 101-155.

[3] Barbosa, M.H.P. and Silveira, L.C.I. (2010) Melhoramento Genético e Recomendação de Cultivares. In: Santos, F., Borém, A. and Caldas, C., Eds., Cana-deaçúcar Bioenergia, Açúcar e Álcool-Tecnologias e Perspectivas, Suprema, Viçosa, 313-331.

[4] Macedo, G.A.R., Silveira, L.C.I., Andrade, L.A.B., Costa, E.L., Oliveira, S.G. and Matter, U.F. (2009) Variedades de cana-de-açúcar para a produção de cachaça de alambique. Informe Agropecuário, 30, 20-24.

[5] Coleti, J.T. and Stupielo, J.J. (2006) Plantio da cana-de-açúcar. In: Segato, V.S., Pinto, A.S., Jendiroba, E. and Nóbrega, J.C.M., Eds., Atualização em produção de cana-de-açúcar, Piracicaba, 139-153.

[6] Yokoya, F. (1995) Fabricação de Aguardente de Cana. Fundação Tropical de Pesquisas e Tecnologia André Tosello, Campinas.

[7] Maia, A.B.R.A. (1994) Componentes secundários da aguardente. STAB-Açúcar, Álcool e Subprodutos, 12, 29-34.

[8] Leaute, R. (1990) Distillation in Alembic. American Journal of Enology and Viticulture, 41, 90-103.

[9] Brazil (2005) Ministry of Agriculture, Livestock and Supply. Normative Instruction No. 13 of 29th on July 2005. Official Journal of Federative Republic of Brazil, 124, 3.

[10] Nascimento, R.F., Marques, J.C., Lima Neto, B.S., Keukeleire, D. and Franco, D.W. (1997) Qualitative and Quantitative High-Performance Liquid Chromatographic Analysis of Aldehydes in Brazilian Sugar Cane Spirits and Other Distilled Alcoholic Beverages. Journal of Chromatography A, 782, 13-23. https://doi.org/10.1016/S0021-9673(97)00425-1

[11] Nascimento, E.S.P., Cardoso, D.R. and Franco, D.W.J. (2008) Quantitative Ester Analysis in Cachaça and Distilled Spirits by Gas Chromatography-Mass Spectrometry (GC-MS). Journal of Agricultural and Food Chemistry, 35, 5488-5493. https://doi.org/10.1021/jf800551d

[12] Souza, P.P., Cardeal, Z.L., Augusti, R., Morrison, P. and Marrio, P.J. (2009) Determination of Volatile Compounds in Brazilian Distilled Cachaça by Using Comprehensive Two-Dimensional Gas Chromatography and Effects of Production Pathways. Journal of Chromatography $A, 1216,2881-2890$.

https://doi.org/10.1016/j.chroma.2008.10.061

[13] Kontoudakis, N., Esteruelas, M., Fort, F., Canals, J.M., Freitas, V. and Zamora, F. (2011) Influence of the Heterogeneity of Grape Phenolic Maturity on Wine Composition and Quality. Food Chemistry, 124, 767-774. https://doi.org/10.1016/j.foodchem.2010.06.093

[14] Bindon, K., Varela, C., Kennedy, J., Holt, H. and Herderich, M. (2013) Relationships between Harvest Time and Wine Composition in Vitis vinifera L. cv. Cabernet Sauvignon 1. Grape and Wine Chemistry, 138, 1696-1705.

[15] Barbosa, M.H.P., Silveira, L.C.I., Macêdo, G.A.R. and Paes, J.M.V. (2007) Variedades melhoradas de cana-de-açúcar para Minas Gerais. Informe Agropecuário, 28, 20-24.

[16] Ribeiro, A.C., Guimarães, P.T.G. and Alvarez, V.H. (1999) Recomendação para o uso de corretivos e fertilizantes em Minas Gerais $5^{\text {a }}$ aproximação. UFV, Viçosa.

[17] Ometto, J.C. (1981) Bioclimatologia Vegetal. Agronômica Ceres, São Paulo.

[18] Conselho dos produtores de cana-de-açúcar, açúcar e álcool do Estado de São Paulo (CONSECANA-SP) (2006) Manual de Instruções. CONSECANA, Piracicaba. 
[19] Vicente, M.A., Fietto, L.G., Castro, I.M., Santos, A.N.G., Coutrim, M.X. and Brandão, R.L. (2006) Isolation of Saccharomyces cerevisiae Strains Producing Higher Levels of Flavoring Compounds for Production of "Cachaça" the Brazilian Sugarcane Spirit. International Journal of Food Microbiology, 108, 51-59. https://doi.org/10.1016/j.ijfoodmicro.2005.10.018

[20] Vasconcelos, J.N. (2010) Fermentação Etanólica. In: Santos, F., Borém, A. and Caldas, C., Eds., Cana-de-açúcar Bioenergia, Açúcar e Álcool-Tecnologias e Pespectivas, Suprema, Viçosa, 401-403.

[21] Fernandes, A.C. (2011) Cálculos na Agroindústria da Cana-de-açúcar. 3rd Edition, STAB, Piracicaba.

[22] INMET (Insituto Nacional de Meteorologia) National Institute of Meteorology) (2016) Meteorological Observation. Brasília. www.inmet.gov.br

[23] Ripoli, T.C.C. and Ripoli, M.L.C. (2004) Biomassa de cana-de-açúcar: Colheita, energia e ambiente. Livroceres, Piracicaba.

[24] Stupielo, J.P. (2005) Manitol: Indicador que antecipa problemas de processos. STAB, Piracicaba, 23, 24.

[25] Cardoso, M.G. (2006) Análises físico-químicas de aguardente. In: Cardoso, M.G., Ed., Produção de Aguardente de Cana, 2nd Edition, UFLA, Lavras, 203-232.

[26] Janzantti, N.S. (2004) Compostos voláteis e qualidade de sabor da cachaça. PhD Thesis, Universidade Estadual de Campinas, Campinas.

[27] Cherubin, R.A. (1998) Efeitos da adição de benzoato de sódio na fermentação alcoólica para produção de aguardente de cana-de-açúcar (Saccharum ssp). PhD Dissertation, Universidade de São Paulo, São Paulo.

[28] Odello, L., Braceschi, L.O., Paolo, G., Seixas, F.R.F., Silva, A.A., Galinaro, C.A. and Franco, D.W. (2009) Avaliação sensorial de cachaça. Química Nova, 32, 1839-1844. https://doi.org/10.1590/S0100-40422009000700029

[29] Nascimento, E.S.P. (2007) Ésteres em aguardente de cana: Seu perfil. PhD Dissertation, Universidade de São Paulo, São Paulo.

Submit or recommend next manuscript to OALib Journal and we will provide best service for you:

- Publication frequency: Monthly

- 9 subject areas of science, technology and medicine

- Fair and rigorous peer-review system

- Fast publication process

- Article promotion in various social networking sites (LinkedIn, Facebook, Twitter, etc.)

- Maximum dissemination of your research work

Submit Your Paper Online: Click Here to Submit

Or Contact service@oalib.com 